\title{
Review Article \\ Sucupira as a Potential Plant for Arthritis Treatment and Other Diseases
}

\author{
Jaqueline Hoscheid and Mara Lane Carvalho Cardoso \\ Postgraduate Program in Pharmaceutical Sciences, State University of Maringá, Avenida Colombo 5790, \\ 87020-900 Maringá, PR, Brazil
}

Correspondence should be addressed to Jaqueline Hoscheid; jaqueline.hoscheid@gmail.com

Received 12 July 2015; Accepted 18 October 2015

Academic Editor: Shigeru Kotake

Copyright (C) 2015 J. Hoscheid and M. L. C. Cardoso. This is an open access article distributed under the Creative Commons Attribution License, which permits unrestricted use, distribution, and reproduction in any medium, provided the original work is properly cited.

\begin{abstract}
Trees of the genus Pterodon, commonly known as "sucupira-branca" or "faveira," are native to central Brazil. The Pterodon fruits are traditionally used in ethnomedicine as an infusion, in small doses, and at regular time intervals as an antirheumatic, anti-inflammatory, tonic, and depurative agent. The various compounds present in the Pterodon class are, generally, waterinsoluble and derived from the fusion of high-molecular weight pentacarbonate units. Scientific research has shown that the major compounds isolated from Pterodon species are linear and/or tetracyclic diterpenes with vouacapane skeletons that partly underlie the pharmacological activities of the fruit-derived oil. Material from Pterodon species has several biological properties, such as analgesic, anti-inflammatory, and anticancer effects. Therefore, recent studies have sought to microencapsulate these extracts to protect them from potential chemical degradation and improve their water solubility, ensuring greater stability and quality of the end products. This review presents a succinct overview of the available scientific evidence of the biological activity and toxicity of Pterodon species in addition to other important aspects, including phytochemical and technological features.
\end{abstract}

\section{Introduction}

The fruits of the genus Pterodon, known as "sucupira," are sold in popular markets and are used in traditional medicine where they are ingested in small amounts and at regular time intervals for the treatment of rheumatism, sore throat, and respiratory disorders (bronchitis and tonsillitis), in addition to their anti-inflammatory, analgesic, purifying, tonic, and hypoglycemic activities [1-4].

The medicinal properties of the plants from the genus Pterodon were investigated at the same time when the first active metabolites were isolated, based on folk medicine where wine, cachaça, or boiling water (tea) infusions of the plants are used $[5,6]$. Studies have shown that linear terpenes, geranylgeraniol derivatives, and tetracyclic diterpenes, which have a vouacapane or vinhaticane skeleton, partly underlie the pharmacological activities of the extracted Pterodon fruit oil [6-12]. To assess the toxicity, the biochemical, hematological, and clinical parameters were determined in previous studies [11, 13]. The increasing use of the herbal Pterodon drugs aroused concern about their effectiveness. Therefore, several researchers have sought to preserve the characteristics of the plant extracts, since improper processing of the plants may result in degradation of the active compounds and, therefore, the loss of pharmacological activity [14-16]. This review presents a scientific overview of "sucupira" trees with reference to their ethnobotanical uses, phytochemistry, biological activity, and toxicity as well as the technological aspects of development phytotherapeutics.

\section{The Genus Pterodon}

According to the list of Brazilian flora species, the genus Pterodon (Fabaceae/Leguminosae) comprises four species native to Brazil: P. abruptus Benth., P. appariciori Pedersoli, $P$. pubescens Benth., and $P$. emarginatus Vog. (synonymous with $P$. polygalaeflorus Benth.) [17] which are commonly known as "faveira," "sucupira," "sucupira-branca," "fava-desucupira," or "sucupira-lisa" [18]. The plants are distributed disjunctively and mixed populations have not been observed, 


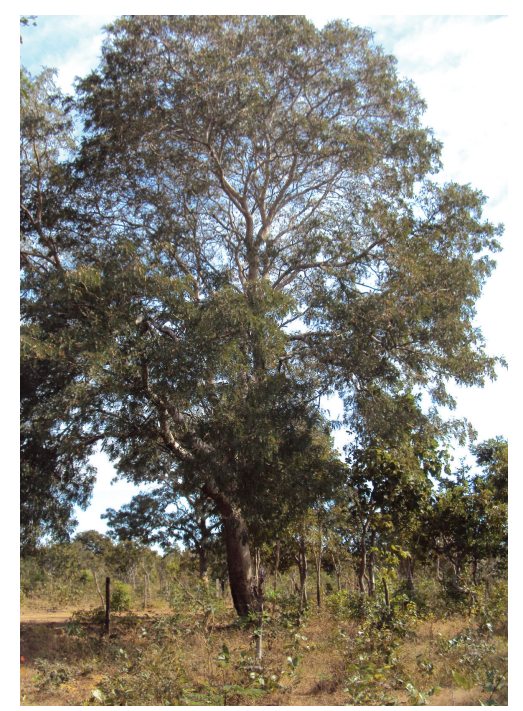

(a)

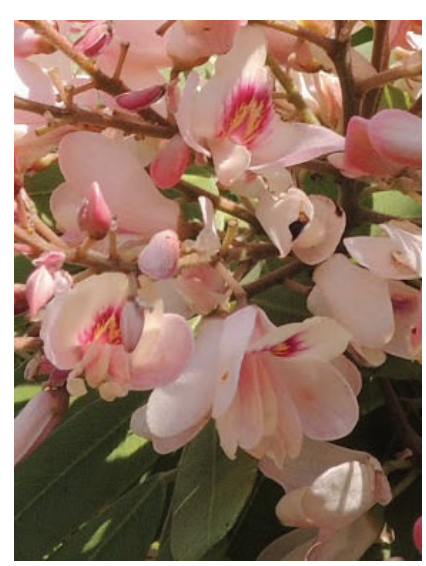

(b)

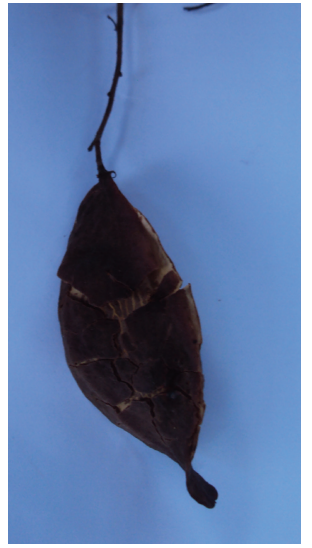

(c)

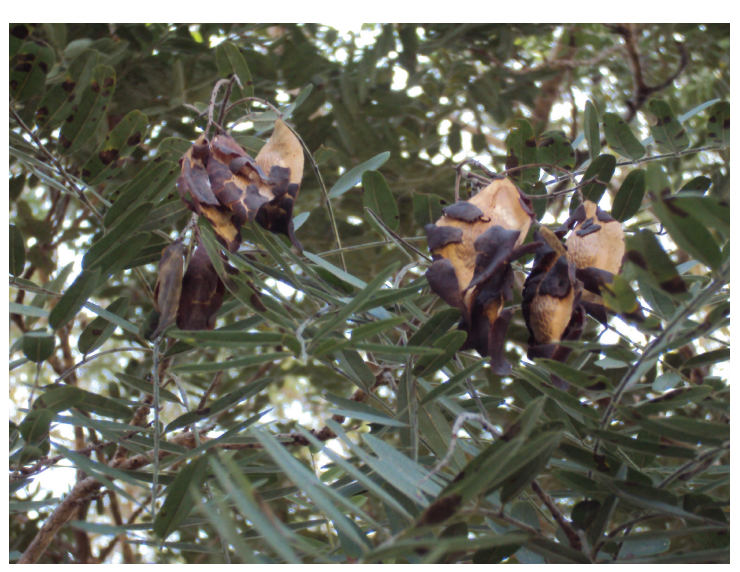

(d)

Figure 1: Photographs of the Pterodon pubescens tree in habitat (a), flowers (b), fruit (c), and a fruiting branch (d). Photographs courtesy of Dr. Mara Lane Carvalho Cardoso.

which may indicate that certain soil characteristics are a limiting factor in the plants' development [19]. In general, these species are aromatic, native trees growing 6-18 $\mathrm{m}$ tall, and are distributed throughout the central region of Brazil, especially in the Cerrado (Goiás, Minas Gerais, São Paulo, Tocantins, Mato Grosso, and Mato Grosso do Sul) and the semideciduous forest of the Paraná Basin [20, 21]. Despite their slow growth, Pterodon species are tolerant to direct sunlight and low soil fertility and are therefore important in mixed reforestation for the recovery of degraded areas [22].

P. pubescens has pinnate leaves containing 20-36 leaflets. Its wood is often used in naval and civil constructions because of its heavy, compact tissue and long durability even when in contact with soil and moisture (Figure 1(a)) [23]. The flowers have a whitish or rosy coloring and are arranged in axillary and apical panicles (Figure 1(b)) [18]. The fruit matures from June to July when the plant is almost completely stripped of its foliage [20]. The fruit pods are of the rounded samara type, indehiscent and winged, containing only a heavily protected seed within a fibrous, wooden capsule that is wrapped externally by a bitter, oily substance in a sponge (Figures 1(c) and 1(d)) [18, 20]. The fruits contain a core endosperm enveloped in peripheral cells, with rich and dense lipid substance content [22]. The fruits can either be collected directly from the trees in the season when the fruits start falling or after they have fallen from the trees. They may be used directly for sowing purposes or opened for removal of the seed before planting. One kilogram of fruit material contains approximately 1200 fruits [20].

$P$. pubescens shares several similarities with $P$. emarginatus and their shared common name is often the cause for confusion. However, P. emarginatus grows in regions north of those of P. pubescens in Brazil and the main differences between the two subtypes are the blue-violet flowers and the length of $P$. emarginatus trees, which can be up to $15 \mathrm{~m}$, while $P$. pubescens grows to a height of 5-10 $\mathrm{m}$ [20]. The appropriate way to differentiate between the Pterodon species is by evaluating the anatomical structure of the extrafloral nectaries, which exist in the rachis and are located under the insertion of each petiole. The basic difference between 


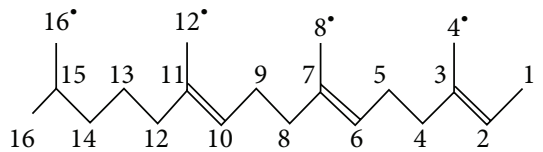

(a)

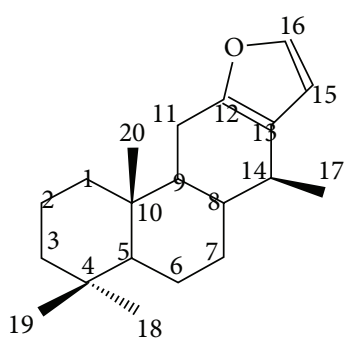

(b)

FIGURE 2: Basic structure of diterpenes: (a) linear diterpene and (b) vouacapane skeleton.

these two subspecies is the density of the pubescence, which is always greater in P. pubescens [19]. P. pubescens fruits are also often confused with those of Bowdichia virgilioides Kunth., a medium-sized tree found in the tropical rainforests of South America and known in folk medicine as "sucupira-preta" $[24,25]$.

\section{Phytochemistry}

The improvement of the purification and isolation methods using mass and ultraviolet spectrometry and infrared and nuclear magnetic resonance techniques has allowed the elucidation of complex structures in plant materials [26, 27]. Phytochemical studies on the genus Pterodon have demonstrated the presence of isoflavones, sesquiterpenes, and diterpenes in its fruit oil [1, 28-30]; isoflavones and triterpenes in the wood [31, 32]; alkaloids, saponins, glycosides, and steroids in the bark of the trees [24,33]; and steroids, sesquiterpenes, isoflavones, and saponins in the leaves $[34,35]$.

The main isolated compounds of these species are diterpenes, which belong to the group of terpenes or terpenoids and constitute the largest class of secondary metabolites. The various substances of this class are, generally, waterinsoluble and are derived from the fusion of pentacarbon units, which have a branched isopentane backbone. These substances are classified according to the number of units they contain, which may have extensive metabolic changes. The 10-, 15-, and 20-carbon terpenes are called monoterpenes, sesquiterpenes, and diterpenes, respectively. The largest terpenes include the triterpenes (30-carbon), tetraterpenes (40carbon), and polyterpenoids [36]. The essential constituents of the Pterodon species are linear and/or tetracyclic diterpenes with a vinhaticane or vouacapane skeleton (Figures 2(a) and 2(b)) [37].

Early identification studies of the compounds present in the genus Pterodon were performed in the 1960s. Mors et al. [38] identified the diterpenes 14,15-epoxygeranylgeraniol and geranylgeraniol in the oil of $P$. pubescens fruits, which proved to be efficient as chemoprophylactic agents in schistosomiasis. Since then, a wide variety of compounds was isolated. Table 1 summarizes the main molecules published in the literature to date.

Since the discovery of furan diterpenes, especially $6 \alpha, 7 \beta$ dihydroxyvouacapan-17 $\beta$-oic acid, they have been used as a prototype for the synthesis of novel molecules with different biological activities in several studies [39-41]. It is believed that the biological activities of the oil from the seeds of the species of the genus Pterodon are directly related to the furan diterpenes content [9].

Based on these findings, it becomes clear that the compounds present in the fruits of the species of the genus Pterodon are highly similar, which suggests that these compounds may have similar biological and pharmacological activities. However, botanical and chemical similarities often hinder interspecies differentiation.

Environmental and genetic factors may affect the development of several plant species, in particular that of aromatic species. For example, the qualitative and quantitative variations of secondary metabolites [42] that directly influence the quality of the medicinal plant are related to domestication of the species, as was observed by Alves et al. [43] when evaluating the essential oil of $P$. emarginatus fruits collected from five different locations of the Cerrado.

\section{Physicochemical Properties}

A few studies have characterized the physicochemical properties of the oil extracted from species of the genus Pterodon. Hoscheid et al. [14], using gas chromatography-mass spectrometry (GC-MS), identified the predominant diterpene observed in the chromatographic profile of the hexane fraction of the ethanol extract of $P$. pubescens as 14,15epoxygeranylgeraniol (retention time: $34.41 \mathrm{~min}$.). According to the authors, compounds with a retention time between 42.21 and $48.02 \mathrm{~min}$ correspond to vouacapane derivatives present in the analyzed fraction.

Reinas et al. [16] have used thermal and infrared analysis methods to analyze the oilseed fraction of $P$. pubescens fruits and found a $0.11 \%$ residual mass at $500^{\circ} \mathrm{C}$ by differential scanning calorimetry (DSC) and thermogravimetric analysis (TGA). The oil absorption spectra in the infrared region (FTIR) showed bands at $1745 \mathrm{~cm}^{-1}$ (assigned to the $\mathrm{C}=\mathrm{O}$ stretching of acetates), at $1244 \mathrm{~cm}^{-1}$ (indicating the asymmetric C$\mathrm{O}$ stretching of acetates), at $1017 \mathrm{~cm}^{-1}$ (denoting asymmetric stretching of C-O-C esters), and at $732 \mathrm{~cm}^{-1}$ (reflecting a furan ring). Furthermore, Fourier transform Raman (FTRaman) spectroscopy analysis showed a peak at $1673 \mathrm{~cm}^{-1}$, reflective of the ester group of vouacapanes [16]. These data are useful for future inter- or intraspecies comparison of the physicochemical characteristics of the fruits' oilseed fraction. 
Table 1: Phytochemical investigations of Pterodon sp.

\begin{tabular}{|c|c|c|}
\hline Part used & Compound & Reference \\
\hline \multicolumn{3}{|c|}{ Pterodon pubescens } \\
\hline \multirow{21}{*}{ Fruits } & 14,15-Epoxygeranylgeraniol & {$[38]$} \\
\hline & Geranylgeraniol & {$[38]$} \\
\hline & 16-Epoxygeranylgeraniol & {$[44]$} \\
\hline & 16,17-Epoxygeranylgeraniol & {$[44]$} \\
\hline & $6 \alpha$-Hydroxy-7 $\beta$-acetoxyvouacapan-14(17)-ene & {$[45]$} \\
\hline & $7 \beta$-Acetoxyvouacapane & {$[45]$} \\
\hline & Methyl $6 \alpha, 7 \beta$-dihydroxyvouacapan-17 $\beta$-oate & {$[45]$} \\
\hline & Methyl $6 \alpha$-acetoxy- $7 \beta$-hydroxyvouacapan- $17 \beta$-oate & {$[45]$} \\
\hline & Vouacapan- $6 \alpha, 7 \beta, 14 \beta, 19$-tetraol & {$[46]$} \\
\hline & $6 \alpha$-Acetoxy-7 $\beta$-hydroxyvouacapane & [9] \\
\hline & $7 \beta$-Diacetoxyvouacapane & {$[9]$} \\
\hline & $6 \alpha, 7 \beta$-Dihydroxyvouacapan-17 $\beta$-methylene-ol & {$[9]$} \\
\hline & $6 \alpha, 7 \beta$-Dihydroxyvouacapan-17 $\beta$-oate methyl ester & {$[10]$} \\
\hline & $6 \alpha, 7 \beta$-Diacetoxyvouacapane & {$[47]$} \\
\hline & Epoxyfarnesol & {$[47]$} \\
\hline & E-Cariofilene & {$[48]$} \\
\hline & $\gamma$-Muurolene & {$[48]$} \\
\hline & Bicyclogermacrene & {$[48]$} \\
\hline & $6 \alpha$-Acetoxyvouacapane & {$[48]$} \\
\hline & $6 \alpha, 7 \beta$-Dimethoxyvouacapan-17-ene & {$[48]$} \\
\hline & Methyl $6 \alpha$-hydroxy-7 $\beta$-acetoxyvouacapan-17 $\beta$-oate & {$[14,15]$} \\
\hline \multirow{3}{*}{ Wood } & $3^{\prime}, 4^{\prime}, 6,7$-Tetramethoxyisoflavone & [31] \\
\hline & $2^{\prime}, 6,7-$ Trimethoxy- $4^{\prime}, 5^{\prime}$-methylenedioxyisoflavone & {$[31]$} \\
\hline & $2^{\prime}, 3^{\prime}, 4^{\prime}, 6,7-$ Pentamethoxyisoflavone & {$[31]$} \\
\hline \multicolumn{3}{|c|}{ Pterodon emarginatus } \\
\hline \multirow{15}{*}{ Fruits } & 14,15-Dihydroxy-14,15-dihydrogeranylgeraniol & [49] \\
\hline & $6 \alpha, 7 \beta$-Diacetoxyvouacapan- $14 \beta$-al & {$[28]$} \\
\hline & $6 \alpha, 7 \beta$-Diacetoxyvouacapan- $14 \beta$-oate & {$[28]$} \\
\hline & Methyl $6 \alpha, 7 \beta$-diacetoxy-14-hydroxyvinhaticoate & {$[28]$} \\
\hline & Methyl $6 \alpha, 7 \beta$-diacetoxy-12,16-dihydro-12,14-dihydroxy-16-oxovinhaticoate & {$[28]$} \\
\hline & Trans-caryophyllene & {$[50]$} \\
\hline & $\beta$-Elemene & {$[50]$} \\
\hline & Germacrene D & {$[50]$} \\
\hline & Spathulenol & {$[50]$} \\
\hline & $\alpha$-Humulene & {$[50]$} \\
\hline & Bicyclogermacrene & {$[50]$} \\
\hline & $6 \alpha, 7 \beta$-Dihydroxyvouacapan-17 $\beta$-oic acid & {$[51]$} \\
\hline & Lupeol & {$[52]$} \\
\hline & 14,15-Epoxygeranylgeraniol & {$[6]$} \\
\hline & $\beta$-Caryophyllene & {$[12]$} \\
\hline \multirow{11}{*}{ Leaves } & $\gamma$-Muurolene & {$[34]$} \\
\hline & Bicyclogermacrene & {$[34]$} \\
\hline & Stigmasterol & {$[34]$} \\
\hline & $\beta$-Sitosterol & {$[34]$} \\
\hline & Vicenin-2 & {$[35]$} \\
\hline & Schaftoside & {$[35]$} \\
\hline & Chrysoeriol-8-C-glucosyl-2" -O-glucuronide-6- $C$-arabinoside & {$[35]$} \\
\hline & Luteolin-7-O-rutinoside & {$[35]$} \\
\hline & Oleanane-type saponins & {$[35]$} \\
\hline & Hederagenin derivatives & {$[35]$} \\
\hline & Aglycone B & {$[35]$} \\
\hline
\end{tabular}


TABle 1: Continued.

\begin{tabular}{|c|c|c|}
\hline Part used & Compound & Reference \\
\hline \multicolumn{3}{|c|}{ Pterodon apparicioi } \\
\hline \multirow{2}{*}{ Fruits } & $7 \beta$-Acetoxyvouacapane & {$[28]$} \\
\hline & Methyl $6 \alpha$-acetoxy-7 $\beta$-hydroxyvouacapan-17 $\beta$-oate & [28] \\
\hline \multicolumn{3}{|c|}{ Pterodon polygalaeflorus } \\
\hline \multirow{33}{*}{ Fruits } & $6 \alpha, 7 \beta$-Dihydroxyvouacapan-17 $\beta$-oic acid & {$[28]$} \\
\hline & Methyl $6 \alpha, 7 \beta$-dihydroxyvouacapan-17 $\beta$-oate & [28] \\
\hline & Methyl $6 \alpha$-acetoxy- $7 \beta$-dihydroxyvouacapan-17 $\beta$-oate & [28] \\
\hline & Vouacapane- $6 \alpha, 7 \beta, 14 \beta$-triol & {$[28]$} \\
\hline & Methyl $6 \alpha$-acetoxy-7 $\beta$-hydroxyvouacapan-17 $\beta$-oate & [37] \\
\hline & $6 \alpha$-Hydroxy-7 $\beta$-acetoxyvouacap-14(17)-ene & {$[37]$} \\
\hline & $6 \alpha$-Hydroxyvouacapane & {$[1]$} \\
\hline & Vouacapane- $6 \alpha, 7 \beta, 14 \beta, 19$-tetraol & [1] \\
\hline & Taxifolin & {$[1]$} \\
\hline & $6 \alpha$-Acetoxyvouacapane & {$[53]$} \\
\hline & Vouacapane & [53] \\
\hline & Trans-caryophyllene & {$[54]$} \\
\hline & $\alpha$-Copaene & {$[54]$} \\
\hline & $\gamma$-Muurolene & {$[54]$} \\
\hline & $\alpha$-Humulene & {$[54]$} \\
\hline & Alloaromadendrene & {$[54]$} \\
\hline & Bicyclogermacrene & [54] \\
\hline & $\delta$-Cadinene & {$[54]$} \\
\hline & $\alpha$-Cubenene & {$[54]$} \\
\hline & $\gamma$-Cadinene & {$[54]$} \\
\hline & $\beta$-Gurjunene & {$[54]$} \\
\hline & Aromadendrene & {$[54]$} \\
\hline & $\alpha$-Calacorene & [54] \\
\hline & $\delta$-Elemene & {$[54]$} \\
\hline & $\alpha$-Gurjunene & {$[54]$} \\
\hline & $\beta$-Elemene & {$[54]$} \\
\hline & Spathulenol & {$[54]$} \\
\hline & Germacrene D & {$[54]$} \\
\hline & $\beta$-Caryophyllene & {$[4]$} \\
\hline & Farnesol & {$[30]$} \\
\hline & Caryophyllene oxide & {$[30]$} \\
\hline & $\beta$-Humulene & {$[30]$} \\
\hline & Methyl-7 $\beta$-acetoxy- $6 \alpha$-hydroxyvouacapan- $17 \beta$-oate & {$[30]$} \\
\hline \multirow{10}{*}{ Wood } & 6,7-Dimethoxy-3', $4^{\prime}$-methylenodioxyisoflavone & {$[32]$} \\
\hline & 3,4,6,7-Tetramethoxyisoflavone & {$[32]$} \\
\hline & $4^{\prime}$-Hydroxy-3',6,7-trimethoxyisoflavone & {$[32]$} \\
\hline & $2^{\prime}, 6,7$-Trimethoxy-3 $3^{\prime}, 4^{\prime}$-methylenedioxyisoflavone & {$[32]$} \\
\hline & $2^{\prime}, 4^{\prime}, 5,6,7$-Pentamethoxyisoflavone & {$[32]$} \\
\hline & $2^{\prime}, 3^{\prime}, 4^{\prime}, 6,7-$ Pentamethoxyisoflavone & {$[32]$} \\
\hline & 6-Methoxy-7-0-acetyl-3', $4^{\prime}$-Methylenedioxyisoflavone & {$[32]$} \\
\hline & Lupeol & {$[32]$} \\
\hline & Betulin & {$[32]$} \\
\hline & 4-Methoxybenzoic & {$[32]$} \\
\hline
\end{tabular}

\section{Traditional Use and Biological Activities}

5.1. The Use in Traditional Medicine. Fruits from the species of the genus Pterodon are sold on popular markets and are used in traditional medicine in small doses and at regular time intervals for the treatment of rheumatism, sore throats, and respiratory disorders (bronchitis and tonsillitis). These therapeutic effects are owing to the fruits' anti-inflammatory, analgesic, purifying, tonic $[1,3,55]$, and hypoglycemic activities [2]. Fruit infusions can also be applied externally against 
acne and skin patches [3]. The active metabolites of Pterodon species were isolated and their medicinal properties were investigated based on folk medicine where wine, cachaça, or boiling water (tea) infusions of the plants are used [5].

5.2. Antinociceptive Activity. The antinociceptive potential of the fruits of Pterodon species has been demonstrated for both the oil extract and its fractions as well as for the isolated diterpenes. The ethanol extract of $P$. polygalaeflorus demonstrated a significant analgesic effect at a dose of $200 \mathrm{mg} / \mathrm{kg}$ body weight (b.w.), as assessed by the inhibition of contractions induced by acetic acid, dextran, and formalin in vivo animal models, explaining its traditional use in the treatment of respiratory diseases in the northeastern regions of Brazil [56].

The antinociceptive properties of the ethanol extract and those of the dichloromethane and hexane fractions $(130 \mathrm{mg} /$ $\mathrm{kg}$ b.w., p.o.) from $P$. pubescens seeds were also shown to be promising in the treatment of pain disorders, with the effect attributable to the vouacapane derivatives as identified in the same study [45]. These findings were supported by the effect of the intragastric infusion of the oily extract of the same species (10-100 mg/kg b.w.) in models of acute and chronic pain, in which the analgesic potential was significant in both models, inhibiting the mechanical and thermal hyperalgesia in postoperative and complex regional pain syndrome [48].

A comparative study on the ethanolic, hexane, and dichloromethane extracts of $P$. polygalaeflorus fruits demonstrated an increased antinociceptive effect of the hexane extract (100\% inhibition) achieved at lower doses $(0.5 \mathrm{mg} / \mathrm{kg}$ b.w., p.o.) compared to that observed for isolated vouacapane derivatives in other studies. This indicates the existence of a synergistic effect of the compounds present in the extract. Phytochemical analysis identified that $90 \%$ of the material was composed of sesquiterpene hydrocarbons, oxygenated sesquiterpenes, and furan diterpenes [30].

The central and peripheral analgesic effect of the essential oil and the hexane, methanol, and butanol fractions of $P$. emarginatus seeds $(100,300$, and $500 \mathrm{mg} / \mathrm{kg}$ b.w.) were first demonstrated by Dutra et al. [57] by the significant reduction of abdominal writhing and the number of paw licking events, and the increase in the latency in the hot plate test. The potential involvement of opioid peptides in the mechanism of action underlying $6 \alpha-7 \beta$-dihydroxyvouacapan-17 $\beta$-oate extracted from $P$. polygalaeflorus was investigated in the acetic acid-induced writhing response mouse model and in the carrageenan-induced inflammatory hyperalgesia rat model. Vouacapane caused dose-dependent analgesia in both models when administered orally, subcutaneously, and intraperitoneally, showing that the release of endorphins may be involved in the mechanism underlying diterpene's analgesic effect [58]. A synergistic analgesic effect was observed when clonidine or dopamine was associated with vouacapane, indicating, at least partly, the activation of the catecholaminergic system [59].

Other compounds, such as geranylgeraniol and $6 \alpha, 7 \beta-$ dihydroxyvouacapan-17 $\beta$-oate methyl ester from $P$. pubescens and $6 \alpha, 7 \beta$-dihydroxyvouacapan-17 $\beta$-oic acid from $P$. emarginatus, were evaluated separately to verify their contributions to the antinociceptive activity of the crude extracts $[10$,
$51,60]$. Geranylgeraniol and $6 \alpha, 7 \beta$-dihydroxyvouacapan$17 \beta$-oate methyl ester demonstrated activities related to the inhibition of vanilloid receptors (VR1), glutamate peripheral receptors [10], and the synthesis and release of serotonin [60]. The compound $6 \alpha, 7 \beta$-dihydroxyvouacapan-17 $\beta$ oic acid showed a predominant peripheral analgesic effect, even when used alone [51]. In addition, a synergistic effect was observed among the isolates and other metabolites present in the extracts, based on the fact that the crude extract (300 mg/kg b.w., p.o.), which contained small amounts of all compounds studied, had statistically identical effects when administered at the same dose as that of the pure compounds tested separately [10].

A more recent study indicated that the antinociceptive activity of the hydroethanolic extract from $P$. emarginatus leaves (500 and $1000 \mathrm{mg} / \mathrm{kg}$ b.w.) could have been related to the presence of flavones and hederagenin derivatives, which were identified as the major constituents of the extract [35].

5.3. Anti-Inflammatory Activity. The first studies to elucidate the anti-inflammatory activity of the "sucupira" fruit monitored the performance of mice with type II collagen-induced arthritis $[61,62]$. A significant reduction in the arthritis index scores was achieved by preventive treatment, starting 20 days before the arthritis induction with daily administration ( $5 \mathrm{mg} / \mathrm{kg}$ b.w., p.o.) of the hydroalcoholic extract from $P$. pubescens seeds. These results provide a scientific basis for the popular use of the seed infusions to treat arthritis. Carvalho et al. [7] demonstrated that the hexane extract (500 mg/kg b.w., p.o.) from P. emarginatus fruits had antiinflammatory activity and could inhibit neutrophil migration to the peritoneal cavity and granulomatous tissue formation in vivo. The authors suggested that the anti-inflammatory activity of the extract could be related to the presence of terpene compounds. Others demonstrated the antiedematogenic activity of the ethanol extract and of the fractions of $P$. pubescens [8], as well as the reduction (approximately 68\%) in carrageenan-induced edema by the hydroethanol extract from $P$. polygalaeflorus fruits (200 mg/kg, i.p.) [56].

Eccentric muscle contractions, arising from acute exercise induced by functional electrical stimulation, may result in muscle trauma and, consequently, initiate an inflammatory process. A protective effect of the hexane extract from $P$. emarginatus fruits was observed when administered before and after acute exercise ( $498 \mathrm{mg} / \mathrm{kg}$ b.w., p.o.), confirming the high activity of this oil infusion and, hence, explaining its use against inflammatory processes in folk medicine [63].

Cardoso et al. [5] evaluated the effect of the ethanol extract from $P$. pubescens fruits on the suppression of $\mathrm{T}$ and $\mathrm{B}$ lymphocytes and on nitric oxide production by macrophages and provided evidence that the extract could suppress the cellular and humoral immune responses in healthy rats at lower concentrations $\left(10^{-2} \mathrm{mg} / \mathrm{kg}\right.$ b.w.) than dexamethasone. The demonstrated immunomodulatory activity is a desired effect because of the fruits' potential application in the treatment of patients with immunoinflammatory or chronic autoimmune diseases. Research conducted with the diterpene $6 \alpha, 7 \beta$ dihydroxyvouacapan- $17 \beta$-oic acid (50 mg/kg b.w., p.o.), isolated from $P$. emarginatus, showed a significant inhibition of 
edema in carrageenan- and prostaglandin E2-induced edema models, indicating that this vouacapane derivative is one of the agents responsible for the anti-inflammatory action of the extract from $P$. emarginatus species [51].

Recently, it was demonstrated that the hexane fraction of the ethanol extract from P. pubescens fruits $(250 \mathrm{mg} / \mathrm{kg} / \mathrm{day}$ b.w., p.o.) had an inhibitory effect on acute inflammation in the carrageenan-induced rat model of pleurisy and on chronic inflammation in the complete Freund's adjuvantinduced arthritis rat model [11]. In the same year, the ethanolic, hexane, and dichloromethane extracts from $P$. polygalaeflorus fruits were assessed for their anti-inflammatory capacity. The hexane extract showed a greater potential for reducing signs of inflammation (redness and vasodilation), accompanied by a reduction in the total number of leukocytes in the exudate $(0.01-1 \mathrm{mg} / \mathrm{kg}$ b.w.) and reduced tissue thickening ( $1 \mathrm{mg} / \mathrm{kg}$ b.w.), in the in vivo air pouch model. Furthermore, it inhibited nitrite production in RAW 264.7 cells $(0.1-80 \mu \mathrm{g} / \mathrm{mL})$, demonstrating high anti-inflammatory activity [30]. Finally, trials using $P$. emarginatus essential oil $(100 \mathrm{mg} / \mathrm{kg}$ b.w., p.o.), which is rich in aromatic terpenes and phenylpropanoids, showed significant attenuation of neurological signs, with reduced and limited development of autoimmune encephalomyelitis by the modulation of the Th1/Treg cell balance [12].

Overall, these results encourage the development of novel research on Pterodon species for the development of standardized extracts and formulations with anti-inflammatory potential.

5.4. Antioxidant Activity. Paula et al. [63], in an in vivo study using the hexane extract of $P$. emarginatus fruits, showed that administration of the extract ( $498 \mathrm{mg} / \mathrm{kg}$ b.w., p.o.) before and after functional electrical stimulation abolished most of the oxidative and nitrosative processes in organs after acute exercise, suggesting a high antioxidant activity of the hexane extract. The phenolic and flavonoid content and the antioxidant activity of essential oil and of butanolic, methanolic, hexane, and ethyl acetate extracts from $P$. emarginatus fruits have also been investigated. The use of methanol and butanol as extractor agents increased the levels of the phenolic constituents and, consequently, demonstrated the highest 2,2diphenyl-1-picrylhydrazy (DPPH) radical scavenging activity $\left(\mathrm{IC}_{50}: 10.15\right.$ and $18.89 \mu \mathrm{g} / \mathrm{mL}$ for the methanol and butanol extract, resp.) [64].

5.5. Antimicrobial Activity. The chemoprophylactic capacity of the isolated compound 14,15-epoxygeranylgeraniol [38], of oleaginous extracts $[38,65,66]$, and of the fractions composed of diterpene derivatives [28] from $P$. pubescens fruits in schistosomiasis has been studied for several years and by several researchers. Research evaluating the larvicidal activity against Aedes aegypti of the hexane extract $\left(\mathrm{IC}_{50}\right.$ : $23.99 \mu \mathrm{g} / \mathrm{mL}$ ) of P. polygalaeflorus fruits and furan diterpenes $\left(\mathrm{IC}_{50}: 14.69-50.08 \mu \mathrm{g} / \mathrm{mL}\right)$ isolated from these fruits were shown to be promising agents for future repellent formulations [53, 67]. Furthermore, the trypanocidal potential of the geranylgeraniol, hexane, dichloromethane, and ethyl acetate fractions and of the ethanol extract of $P$. pubescens was investigated [68]. Both the hexane fraction, which was composed of geranylgeraniol, and isolated geranylgeraniol inhibited the proliferation of intracellular amastigotes at concentrations that did not affect mammalian host cells (22 and $15 \mu \mathrm{g} / \mathrm{mL}$, resp.). Moreover, they were three times more active than the other fractions, mainly acting on the mitochondria of the epimastigotes and trypomastigotes of Trypanosoma cruzi.

Dutra et al. [69] showed that the essential oil from $P$. emarginatus seeds inhibited the growth of $S$. aureus (minimum inhibitory concentration (MIC): $2.5 \mathrm{mg} / \mathrm{mL}$ ). The hexane and butanol fractions from $P$. emarginatus seeds had significant in vitro activity against Leishmania amazonensis $\left(\mathrm{IC}_{50}: 50.06\right.$ and $46.65 \mu \mathrm{g} / \mathrm{mL}$, resp.). According to the authors, these results indicate that bioactive molecules found in $P$. emarginatus seeds can be used as prototypes for the development of new drugs and/or as sources of raw pharmaceutical materials with antimicrobial and leishmanicidal activities.

The activity of the ethanol extract from P. polygalaeflorus bark against Staphylococcus aureus, Micrococcus flavus, Bacillus cereus, Bacillus subtilis, Salmonella enteritidis, Escherichia coli, Pseudomonas aeruginosa, Proteus mirabilis, Serratia marcescens, Mycobacterium phlei, Mycobacterium smegmatis, and Mycobacterium fortuitum and against the yeasts Candida albicans and Candida krusei was tested and was significant against Mycobacterium phlei only [70]. The evaluation of the antimicrobial activity of $P$. emarginatus bark showed a different outcome since the use of its ethanol extract against Gram-positive and Gram-negative bacteria and against the fungus Candida albicans was effective against Rhodococcus equi, Micrococcus luteus, Micrococcus roseus (MIC: $0.18 \mathrm{mg} / \mathrm{mL}$ ), Serratia marcescens, Pseudomonas aeruginosa (MIC: $0.37 \mathrm{mg} / \mathrm{mL}$ ), Enterobacter cloacae, and C. albicans (MIC: $0.74 \mathrm{mg} / \mathrm{mL}$ ) [33].

However, when the extract was prepared using Brazilian cachaça as extractor liquid and was tested against Bacillus subtilis, Staphylococcus aureus, Escherichia coli, Pseudomonas aeruginosa, Candida albicans, Candida parapsilosis, the promastigote form of Leishmania amazonensis, and poliovirus, it did not show activity at concentrations lower than $1000 \mu \mathrm{g} / \mathrm{mL}$. Several plant species in the Brazilian Cerrado are widely used in ethnomedicine, though the safety and efficacy of medicinal plants used in communities are not always known. The risk of toxicity due to the inappropriate use of herbal drugs should be conveyed to the population [71]. Nevertheless, taking into account that the alcohol content does not exceed $40 \%$ in Brazilian cachaça and that sesquiterpenes and diterpenes are insoluble in water, the choice of liquid extractor could directly affect the extraction of active compounds and, consequently, limit both the antimicrobial activity and the pharmacological toxicity profile of the extracts.

5.6. Anticancer Activity. The inhibition of hepatic preneoplastic lesions and cell proliferation by purified geranylgeraniol renders this compound a promising chemopreventive agent against hepatocarcinogenesis [72]. Several studies using $P$. pubescens fruits have investigated their antiproliferative 
activity against various cancer cell lines. Studies using isolated furan diterpenes, including $6 \alpha$-acetoxy- $7 \beta$-hydroxyvouacapan, $6 \alpha, 7 \beta$-dihydroxyvouacapan-17 $\beta$-oate methyl ester, and $6 \alpha, 7 \beta$-dihydroxyvouacapan-17 $\beta$-methylene-ol, against prostatic cell lines [9] and hexane extract subfractions containing vouacapan- $6 \alpha, 7 \beta, 14 \beta, 19$-tetraol against human melanoma cell lines [46] showed improved antiproliferative effects and a lower toxicity than that found for doxorubicin.

The furan diterpene $6 \alpha, 7 \beta$-dihydroxyvouacapan-17 $\beta$-oic acid isolated from $P$. polygalaeflorus showed promising results as an antiproliferative agent against human cancer cell lines. Likewise, the semisynthetic derivatives $6 \alpha$-hydroxyvouacapan-7 $\beta, 17 \beta$-lactone and 6-oxovouacapan-7 $\beta, 17 \beta$ lactone had effective and selective cytotoxicity against the ovarian cancer cell lines NCI-ADR/RES and OVCAR-03 and erythromyeloblastoid leukemia cells (K562), respectively [41].

The effect of a terpenoid-rich subfraction of purified $P$. pubescens was assessed in the K562 (human myeloid leukemia) and Jurkat (human T-cell acute leukemia) cell lines and was found to be significantly cytotoxic by arresting cell cycle progression and inducing apoptosis [73]. Similarly, Pereira et al. [47] found that subfractions of the hexane extract of $P$. pubescens containing epoxyfarnesol, geranylgeraniol, and vouacapane derivatives (methyl $6 \alpha$-acetoxy-7 $\beta$ hydroxyvouacapan-17 $\beta$-oate and $6 \alpha, 7 \beta$-dihydroxyvouacapan) were able to inhibit the activation of signaling pathways involved in chronic myeloid leukemia cell proliferation and to stimulate cell cycle arrest and apoptosis.

Essential oil of $P$. emarginatus was active against rat glioma $\left(\mathrm{C}_{6}\right)$, human melanoma (MeWo), mouse colon carcinoma $\left(\mathrm{CT}_{26}\right.$.WT), human breast cancer (MDA), human lung carcinoma $\left(\mathrm{A}_{549}\right)$, mouse melanoma $\left(\mathrm{B}_{16}-\mathrm{F}_{1}\right)$, hamster ovary cell (CHO-K1), and hamster kidney fibroblast cell lines (BHK-21) with $\mathrm{IC}_{50}$ of $24.9-47 \mu \mathrm{g} / \mathrm{mL}$. In an in vitro cell viability assay, treatment with the essential oil showed higher viability of peripheral blood mononuclear cells in comparison with doxorubicin treatment. In summary, these data show that essential oil is less cytotoxic against normal cells but has increased cytotoxicity against cancer cells. Oil analysis revealed the presence of $\beta$-elemene, trans-caryophyllene, $\alpha$ humulene, germacrene $\mathrm{D}$, bicyclogermacrene, and spathulenol in concentrations higher than 5\% [29].

The ethanol, hexane, and dichloromethane extracts and 14,15-epoxygeranylgeraniol isolated from $P$. emarginatus demonstrated inhibition of cell proliferation and viability of the human glioblastoma cell line U87MG [6]. These results support the interest in developing new anticancer therapeutics in the near future.

5.7. Muscle Relaxant Activity. The ethanol extract from $P$. polygalaeflorus fruits showed bronchodilator activity in isolated guinea-pig trachea $\left(\mathrm{EC}_{50}: 1.7 \mathrm{mg} / \mathrm{mL}\right)$, supporting its use in respiratory diseases [56]. Similar results were observed for the essential oil of these fruits $(1300 \mu \mathrm{g} / \mathrm{mL})$, which inhibited contractions triggered by electromechanical coupling [42]. In addition, the essential oil of $P$. polygalaeflorus and its main constituent $\beta$-caryophyllene were shown to have antispasmodic activity and to cause muscle tone relaxation in the isolated rat ileum $\left(\mathrm{IC}_{50}: 394.35\right.$ and $68.65 \mu \mathrm{g} / \mathrm{mL}$, resp.); their inhibitory effect on intestinal contractility was primarily mediated through an intracellular mechanism [54].

5.8. Hypoglycemic Activity. There are few reports on the hypoglycemic effect of extracts from Pterodon species. The hypoglycemic activity of tea brewed from the leaves and fruits of $P$. emarginatus was described in a study on the traditional use of plants in communities in the Alto Paraguay Bay and Guapore Valley in Mato Grosso in Brazil [2, 74]. Marked changes in blood glucose levels (18.36\% decrease) were observed in vivo after daily administration of the hexane fraction of $P$. pubescens fruits ( $250 \mathrm{mg} / \mathrm{kg}$ b.w., p.o.) for 21 days [11].

5.9. Lipolytic Activity. Oral administration of the hexane fraction of $P$. pubescens fruits in rats $(250 \mathrm{mg} / \mathrm{kg} / \mathrm{b} . \mathrm{w} . / \mathrm{day}$, p.o.) for 21 days greatly reduced total cholesterol $(34.18 \%)$ and triglyceride levels (41.63\%) compared with those of the control group, without causing changes in water and food consumption. To the best of our knowledge, cholesterol and triglyceride level-lowering effects of extracts from Pterodon species in animals have not been shown in studies previous to the one conducted by Hoscheid et al. [11].

\section{Toxicity}

As important as the activity is the proof of the absence of toxicity. Sabino et al. [75] showed that the extracted oil fraction from $P$. pubescens seeds did not induce acute toxic effects, mutagenicity, and/or cytotoxicity in healthy animals after oral administration of doses significantly higher $(8 \mathrm{~g} / \mathrm{kg}$ b.w.) than those ingested by humans. The absence of acute toxicity was also observed for the hexane fraction from $P$. pubescens fruits at a dose of $1 \mathrm{~g} / \mathrm{kg}$ b.w. [11].

Nevertheless, in mice with type II collagen-induced arthritis, the hydroethanolic extract of $P$. pubescens is therapeutically effective only after several days of treatment, which could result in subacute toxicity in the animals. To verify this, Pinto Coelho et al. [13] determined the biochemical, hematological, and clinical parameters and performed anatomical and histopathological analysis of the organs of animals treated with the hydroethanol extract of $P$. pubescens for 28 days $(5 \mathrm{mg} / \mathrm{kg}$ b.w./day). The authors noted that in addition to reducing the severity of the disease the treatment did not induce any detectable toxic subacute side effects. Similarly, after daily treatment with the hexane fraction of $P$. pubescens (250 mg/kg b.w., p.o.) for 21 days, no anatomical, histological, biochemical, and hematological changes were found in the complete Freund's adjuvant-induced arthritis rat model [11].

In contrast, as described in a case report [76], an outbreak of bovine poisoning in Goiás in Brazil causing illness in 84 animals and the death of seven of them was due to the consumption of the leaves and fruits of $P$. emarginatus. A marked elevation of serum bilirubin levels and the activity of serum alanine and aspartate aminotransferase (ALT and AST, resp.) and gamma glutamyltransferase (GGT) was found. Macroscopic changes, such as hepatomegaly and necrosis 
of multifocal areas in the liver, heart, spleen, lungs, skeletal intercostal muscles, and chest, as well as bleeding were also observed. At the microscopic level, degeneration of the liver and kidneys, hepatocellular necrosis, and biliary hyperplasia were observed.

\section{Development of Phytotherapeutics Containing Oil from Pterodon Species}

Biodiversity, together with the traditional knowledge of communities of popular medicine and the science underlying the biological sciences, has driven the technological development of plant products. Early studies seeking to develop a herbal medicine using extracts from $P$. pubescens were established in the 1980s and 1990s, which followed the earlier finding of a chemoprophylactic effect on schistosomiasis [38]. Different soap formulations were developed and incorporated with the essential oil obtained by the hexane percolation of fruit. The protective efficacy rates ranged from $0 \%$ to $100 \%$ depending on the formulation. In addition, preliminary studies on irritation and toxicity were promising, showing that these formulations had potential in the prevention of schistosomiasis [65, 66].

One of the methods of using $P$. emarginatus to treat rheumatic pains and burns in folk medicine is the use of poultices prepared by steeping the fruits [77]. To prove the activity of this method, the essential oil and the hexane fraction obtained from $P$. emarginatus fruits were incorporated in a cream, and the cream's effect on the healing of skin wounds was tested in rabbits. Both creams had significant antiinflammatory activity, showing a reduction in the number of inflammatory cells and an increase in the number of fibroblasts and blood vessels, explaining its effect and use in traditional medicine [50].

One of the current trends in the manufacture of herbal medicines to ensure the attainment of the desired therapeutic effect is based on the use of standardized dried extracts [78]. Spray-drying the ethanolic extract from P. emarginatus using colloidal silicon dioxide prevented thermal degradation and approximately doubled the terpene content, in line with the increase in the analgesic potential of the dry extract [52]. These results might suggest that the technological process used to transform the oil from P. emarginatus fruits in the dry extract was appropriate since it maintained the quality and therapeutic activity at the level described for plant material.

During the transformation of herbal plant material, the chemical and pharmacological integrity needs to be preserved to ensure a constant composition and therapeutic reproducibility [79]. Therefore, Hoscheid et al. [14] isolated the isomers methyl $6 \alpha$-hydroxy- $7 \beta$-acetoxyvouacapan- $17 \beta$ oate and methyl $6 \alpha$-acetoxy- $7 \beta$-hydroxyvouacapan-17 $\beta$-oate from $P$. pubescens fruits and validated a methodology to quantify the compounds by GC-MS using selected ion monitoring. The analyses were carried out using a system equipped with a HP-5 capillary column and temperature program at $100-270^{\circ} \mathrm{C}$. The method proved to be precise, reproducible, accurate, and robust. Furthermore, vouacapanes were found to be stable in solution for more than 12 days.
Among the alternatives to preserve the plant material characteristics, microencapsulation is superior [79]. Servat et al. [15] microencapsulated $P$. pubescens extract and the isomer mixture of methyl $6 \alpha$-hydroxy-7 $\beta$-acetoxyvouacapan$17 \beta$-oate and $6 \alpha$-acetoxy- $7 \beta$-hydroxyvouacapan-17 $\beta$-oate in maltodextrin and gum arabic using spray-drying. The results of the accelerated stability study and monitoring of the antinociceptive assays demonstrate that microencapsulation is a useful alternative to increase the shelf life, preserve the contents and to solve shortcomings such as low water solubility.

Another microencapsulation method, complex coacervation, was used for the oilseed fraction of the ethanol extract from $P$. pubescens fruits in which the use of a polymeric system consisting of alginate/chitosan with medium- or low-molecular-weight chitosan and a deacetylation degree greater than $75 \%$ was evaluated. The use of the alginate/lowmolecular-weight chitosan polymer system with a mean polymer diameter of $0.5885 \mu \mathrm{m}$ and the highest encapsulation efficiency proved to be most promising. According to the authors, this system has the potential to mask the flavor of the extract and to protect it from possible chemical degradation [16].

\section{Conclusion}

The common constituents of the fruits of the species of the genus Pterodon are linear diterpenes, geranylgeraniol derivatives, and/or tetracyclic diterpenes with vouacapane skeletons. Several other compounds have been isolated from different plant parts, such as flavonoids, saponins, and sesquiterpenes from the leaves. However, the fruit is the main plant material used. Extracts from Pterodon species have several biological properties, such as analgesic, antiinflammatory, and anticarcinogenic effects. Current in vitro and in vivo studies confirm these activities and seek to develop phytotherapeutics using methods that preserve the contents of the plant material and resolve solubility issues. In addition, toxicity assessments and observations that were conducted during biological test assays indicate that therapeutics made from Pterodon species are safe when taken at the recommended doses.

\section{Conflict of Interests}

The authors declare that there is no conflict of interests regarding the publication of this paper.

\section{References}

[1] A. M. C. Arriaga, M. A. B. De Castro, E. R. Silveira, and R. Braz-Filho, "Further diterpenoids isolated from Pterodon polygalaeflorus," Journal of the Brazilian Chemical Society, vol. 11, no. 2, pp. 187-190, 2000.

[2] M. Macedo and A. R. Ferreira, "Plantas hipoglicemiantes utilizadas por comunidades tradicionais na Bacia do Alto Paraguai e Vale do Guaporé, Mato Grosso-Brasil," Revista Brasileira de Farmacognosia, vol. 14, pp. 45-47, 2004.

[3] M. D. F. Agra, K. N. Silva, I. J. L. D. Basílio, P. F. de Freitas, and J. M. Barbosa-Filho, "Survey of medicinal plants used in the 
region Northeast of Brazil," Brazilian Journal of Pharmacognosy, vol. 18 , no. 3, pp. 472-508, 2008.

[4] V. Leonhardt, J. H. Leal-Cardoso, S. Lahlou et al., "Antispasmodic effects of essential oil of Pterodon polygalaeflorus and its main constituent $\beta$-caryophyllene on rat isolated ileum," Fundamental and Clinical Pharmacology, vol. 24, no. 6, pp. 749-758, 2010.

[5] C. C. Cardoso, A. C. Pinto, P. R. Marques et al., "Suppression of $\mathrm{T}$ and $\mathrm{B}$ cell responses by Pterodon pubescens seeds ethanolic extract," Pakistan Journal of Biological Sciences, vol. 11, no. 19, pp. 2308-2313, 2008.

[6] D. Hansen, A. M. Nakahata, M. Haraguchi, O. K. Okamoto, E. Gonçalez, and A. Alonso, "14, 15-epoxygeranylgeraniol and extracts isolated from Pterodon emarginatus vog. fruits: antitumor activity on glioblastoma cells," Journal of Applied Pharmaceutical Science, vol. 2, no. 9, pp. 20-24, 2012.

[7] J. C. T. Carvalho, J. A. A. Sertié, M. V. J. Barbosa et al., "Antiinflammatory activity of the crude extract from the fruits of Pterodon emarginatus Vog," Journal of Ethnopharmacology, vol. 64, no. 2, pp. 127-133, 1999.

[8] M. C. C. Silva, C. R. M. Gayer, C. S. Lopes et al., "Acute and topic anti-edematogenic fractions isolated from the seeds of Pterodon pubescens," Journal of Pharmacy and Pharmacology, vol. 56, no. 1, pp. 135-141, 2004.

[9] H. M. Spindola, J. E. de Carvalho, A. L. T. G. Ruiz et al., "Furanoditerpenes from Pterodon pubescens benth with selective in vitro anticancer activity for prostate cell line," Journal of the Brazilian Chemical Society, vol. 20, no. 3, pp. 569-575, 2009.

[10] H. M. Spindola, L. Servat, C. Denny et al., "Antinociceptive effect of geranylgeraniol and $6 \alpha, 7 \beta$-dihydroxyvouacapan-17 $\beta$ oate methyl ester isolated from Pterodon pubescens Benth," BMC Pharmacology, vol. 10, article 1, 10 pages, 2010.

[11] J. Hoscheid, C. A. Bersani-Amado, B. A. Da Rocha et al., "Inhibitory effect of the hexane fraction of the ethanolic extract of the fruits of pterodon pubescens benth in acute and chronic inflammation," Evidence-Based Complementary and Alternative Medicine, vol. 2013, Article ID 272795, 7 pages, 2013.

[12] T. B. Alberti, R. Marcon, M. A. Bicca, N. R. B. Raposo, J. B. Calixto, and R. C. Dutra, "Essential oil from Pterodon emarginatus seeds ameliorates experimental autoimmune encephalomyelitis by modulating Th1/Treg cell balance," Journal of Ethnopharmacology, vol. 155, no. 1, pp. 485-494, 2014.

[13] M. G. P. Pinto Coelho, P. R. Marques, C. R. M. Gayer, L. C. A. Vaz, J. F. Nogueira Neto, and K. C. D. C. Sabino, "Subacute toxicity evaluation of a hydroalcoholic extract of Pterodon pubescens seeds in mice with collagen-induced arthritis," Journal of Ethnopharmacology, vol. 77, no. 2-3, pp. 159-164, 2001.

[14] J. Hoscheid, A. Reinas, D. A. G. Cortez, W. F. Da Costa, and M. L. C. Cardoso, "Determination by GC-MS-SIM of furanoditerpenes in Pterodon pubescens Benth.: development and validation," Talanta, vol. 100, pp. 372-376, 2012.

[15] L. Servat, H. M. Spindola, R. A. F. Rodrigues et al., "Pterodon pubescens benth: stability study of microencapsulated extract and isolated compounds monitored by antinociceptive assays," Journal of the Brazilian Chemical Society, vol. 23, no. 7, pp. 12441253, 2012.

[16] A. E. Reinas, J. Hoscheid, P. M. Outuki, and M. L. C. Cardoso, "Preparation and characterization of microcapsules of Pterodon pubescens Benth. by using natural polymers," Brazilian Journal of Pharmaceutical Sciences, vol. 50, no. 4, pp. 919-930, 2014.
[17] H. C. Lima, "Pterodon," in Lista de Espécies da Flora do Brasil, R. C. Forzza, J. R. Stehmann, and M. Nadruz, Eds., Jardim Botânico do Rio de Janeiro, Rio de Janeiro, Brazil, 2012.

[18] H. Lorenzi and F. J. A. Matos, Plantas Medicinais no Brasil Nativas e Exótica, Instituto Plantarum, Nova Odessa, Brazil, 2nd edition, 2008.

[19] É. A. S. E Paiva, H. C. de Morais, R. M. dos Santos Isaias, D. M. S. da Rocha, and P. E. Oliveira, "Occurrence and structure of extrafloral nectaries in Pterodon pubescens Benth. and Pterodon polygalaeflorus Benth," Pesquisa Agropecuaria Brasileira, vol. 36, no. 2, pp. 219-224, 2001.

[20] H. Lorenzi, Árvores Brasileiras, Plantarum, Nova Odessa, Brazil, 1998.

[21] S. Barreira, J. R. S. Scolforo, S. A. Botelho, and J. M. de Mello, "Estudo da estrutura da regeneração natural e da vegetação adulta de um cerrado senso stricto para fins de manejo florestal," Scientia Forestalis/Forest Sciences, no. 61, pp. 64-78, 2002.

[22] D. M. T. Oliveira and E. A. S. Paiva, "Anatomy and ontogeny of Pterodon emarginatus (Fabaceae: Faboideae) seed," Brazilian Journal of Biology, vol. 65, no. 3, pp. 483-494, 2005.

[23] H. Lorenzi, Árvores Brasileiras: Manual de Identificação e Cultivo de Plantas Arbóreas Nativas do Brasil, Instituto Plantarum, São Paulo, Brazil, 4th edition, 2002.

[24] R. Torrenegra, P. Bauereiß, and H. Achenbach, "Homoormosanine-type alkaloids from Bowdichia virgiloides," Phytochemistry, vol. 28, no. 8, pp. 2219-2221, 1989.

[25] M. M. Grandtner and J. Chevrette, Dictionary of Trees, Volume 2: South America: Nomenclature, Taxonomy and Ecology, Academic Press, Boston, Mass, USA, 2013.

[26] J. B. Calixto, "Efficacy, safety, quality control, marketing and regulatory guidelines for herbal medicines (phytotherapeutic agents)," Brazilian Journal of Medical and Biological Research, vol. 33, no. 2, pp. 179-189, 2000.

[27] J. Chang, "Medicinal herbs: drugs or dietary supplements?" Biochemical Pharmacology, vol. 59, no. 3, pp. 211-219, 2000.

[28] M. Fascio, W. B. Mors, B. Gilbert et al., "Diterpenoid furans from Pterodon species," Phytochemistry, vol. 15, no. 1, pp. 201203, 1976.

[29] R. C. Dutra, F. Pittella, D. Dittz et al., "Chemical composition and cytotoxicity activity of the essential oil of Pterodon emarginatus," Brazilian Journal of Pharmacognosy, vol. 22, no. 5, pp. 971-978, 2012.

[30] F. D. A. Pinto, M. V. Vigliano, N. R. F. Leal et al., "Phytochemical and pharmacological analysis of Pterodon polygalaeflorus extracts," Pharmacologyonline, vol. 3, pp. 56-70, 2013.

[31] R. Braz Filho, O. R. Gottlieb, and R. M. V. Assumpção, “The isoflavones of Pterodon pubescens," Phytochemistry, vol. 10, no. 11, pp. 2835-2836, 1971.

[32] D. D. Marques, M. I. L. Machado, M. G. Carvalho, L. A. C. Meleira, and R. Braz-Filho, "Isoflavonoids and triterpenoids isolated from Pterodon polygalaeflorus," Journal of the Brazilian Chemical Society, vol. 9, no. 3, pp. 295-301, 1998.

[33] K. G. L. Bustamante, A. D. F. Lima, M. L. Soares et al., "Avaliação da atividade antimicrobiana do extrato etanólico bruto da casca da sucupira branca (Pterodon emarginatus Vogel)_fabaceae," Revista Brasileira de Plantas Medicinais, vol. 12, no. 3, pp. 341345, 2010.

[34] A.P. Santos, D. T.Zatta, W. F. Moraes et al., "Composição química, atividade antimicrobiana do óleo essencial e ocorrência de esteróides nas folhas de Pterodon emarginatus Vogel, Fabaceae," Revista Brasileira de Farmacognosia, vol. 20, no. 6, pp. 891-896, 2010. 
[35] G. Negri, R. Mattei, and F. R. Mendes, "Antinociceptive activity of the HPLC- and MS-standardized hydroethanolic extract of Pterodon emarginatus Vogel leaves," Phytomedicine, vol. 21, no. 8-9, pp. 1062-1069, 2014.

[36] L. Taiz and E. Zeiger, Fisiologia vegetal, Artmed, Porto Alegre, Brazil, 4th edition, 2009.

[37] A. M. Campos, E. R. Silveira, R. Braz-Filho, and T. C. Teixeira, "Diterpenoids from Pterodon polygalaeflorus," Phytochemistry, vol. 36, no. 2, pp. 403-406, 1994.

[38] W. B. Mors, M. F. S. Filho, H. J. Monteiro, B. Gilbert, and J. Pellegrino, "Chemoprophylactic agent in schistosomiasis: 14,15epoxygeranylgeraniol," Science, vol. 157, no. 3791, pp. 950-951, 1967.

[39] V. J. Belinelo, G. T. Reis, G. M. Stefani, D. L. Ferreira-Alves, and D. Piló-Veloso, "Synthesis of $6 \alpha, 7 \beta$-dihydroxyvouacapan$17 \beta$-oic acid derivatives. Part IV: mannich base derivatives and its activities on the electrically stimulated guinea-pig ileum preparation," Journal of the Brazilian Chemical Society, vol. 13, no. 6, pp. 830-837, 2002.

[40] M. M. M. Rubinger, P. A. Castelo-Branco, S. Guilardi et al., "Preparation, X-ray structural studies and plant growth regulatory activity of methyl $6 \alpha, 7 \beta$-thiocarbonyldioxyvouacapan$17 \beta$-oate," Journal of the Brazilian Chemical Society, vol. 15, pp. 219-223, 2004.

[41] F. P. G. Euzébio, F. J. L. dos Santos, D. Piló-Veloso et al., "Effect of $6 \alpha, 7 \beta$-dihydroxyvouacapan-17 $\beta$-oic acid and its lactone derivatives on the growth of human cancer cells," Bioorganic Chemistry, vol. 37, no. 3, pp. 96-100, 2009.

[42] P. P. Botrel, J. E. B. P. Pinto, A. C. C. De Araújo et al., "Variation in the content and volatile composition of Hyptis marrubioides Epl. cultivated in field and greenhouse," Quimica Nova, vol. 33, no. 1, pp. 33-37, 2010.

[43] S. F. Alves, L. L. Borges, J. A. M. de Paula et al., "Chemical variability of the essential oils from fruits of Pterodon emarginatus in the Brazilian Cerrado," Brazilian Journal of Pharmacognosy, vol. 23, no. 2, pp. 224-229, 2013.

[44] M. Fascio, B. Gilbert, W. B. Mors, and T. Nishida, "Two new diterpenes from Pterodon pubescens Benth," Anais da Academia Brasileira de Ciências, vol. 42, pp. 97-101, 1970.

[45] L. P. Coelho, P. A. Reis, F. L. De Castro et al., "Antinociceptive properties of ethanolic extract and fractions of Pterodon pubescens Benth. seeds," Journal of Ethnopharmacology, vol. 98, no. 1-2, pp. 109-116, 2005.

[46] C. R. Vieira, M. F. Marques, P. R. Soares et al., "Antiproliferative activity of Pterodon pubescens Benth. seed oil and its active principle on human melanoma cells," Phytomedicine, vol. 15, no. 6-7, pp. 528-532, 2008.

[47] M. F. Pereira, T. Martino, S. R. Dalmau et al., "Terpenic fraction of Pterodon pubescens inhibits nuclear factor kappa B and extracellular signal-regulated protein Kinase 1/2 activation and deregulates gene expression in leukemia cells," BMC Complementary and Alternative Medicine, vol. 12, article 231, 2012.

[48] C. Nucci, L. Mazzardo-Martins, J. Stramosk et al., "Oleaginous extract from the fruits Pterodon pubescens Benth induces antinociception in animal models of acute and chronic pain," Journal of Ethnopharmacology, vol. 143, no. 1, pp. 170-178, 2012.

[49] J. R. Mahajan and M. B. Monteiro, "New diterpenoids from Pterodon emarginatus," Anais da Academia Brasileira de Ciências, vol. 42, pp. 103-107, 1970.

[50] R. C. Dutra, F. Pittella, A. S. Ferreira, P. Larcher, R. E. Farias, and N. R. Barbosa, "Efeito cicatrizante das sementes de Pterodon emarginatus Vogel em modelos de úlceras dérmicas experimentais em coelhos," Latin American Journal of Pharmacy, vol. 28, no. 3, pp. 375-382, 2009.

[51] C. B. Galceran, J. A. A. Sertie, C. S. Lima, and J. C. T. Carvalho, "Anti-inflammatory and analgesic effects of $6 \alpha, 7 \beta$-dihydroxyvouacapan-17 $\beta$-oic acid isolated from Pterodon emarginatus Vog. fruits," Inflammopharmacology, vol. 19, no. 3, pp. 139-143, 2011.

[52] P. C. Oliveira, E. C. Conceição, P. A. Oliveira et al., "Obtaining a dry extract of Pterodon emarginatus (Fabaceae) fruits by spraydrying," Journal of Pharmacy Research, vol. 5, no. 1, p. 641, 2012.

[53] A. T. A. Pimenta, G. M. P. Santiago, Â. M. C. Arriaga, G. H. A. Menezes, and S. B. Bezerra, "Estudo fitoquímico e avaliação da atividade larvicida de Pterodon polygalaeflorus Benth (Leguminosae) sobre Aedes aegypti," Revista Brasileira de Farmacognosia, vol. 16, no. 4, pp. 501-505, 2006.

[54] G. L. Evangelista, A. N. Coelho-de-Souza, C. F. Santos et al., "Essential oil of Pterodon polygalaeflorus inhibits electromechanical coupling on rat isolated trachea," Journal of Ethnopharmacology, vol. 109, no. 3, pp. 515-522, 2007.

[55] M. P. Correa, Dicionário de Plantas Úteis do Brasil e das Exóticas Cultivadas, Ministério da Agricultura, Instituto Brasileiro de Desenvolvimento Florestal, Brasília, Brazil, 2000.

[56] L. K. A. M. Leal, A. A. G. Ferreira, G. A. Bezerra, F. J. A. Matos, and G. S. B. Viana, "Antinociceptive, anti-inflammatory and bronchodilator activities of Brazilian medicinal plants containing coumarin: a comparative study," Journal of Ethnopharmacology, vol. 70, no. 2, pp. 151-159, 2000.

[57] R. C. Dutra, R. Trevizani, F. Pittella, and N. R. Barbosa, "Antinociceptive activity of the essential oil and fractions of Pterodon emarginatus vogel seeds," Latin American Journal of Pharmacy, vol. 27, no. 6, pp. 865-870, 2008.

[58] I. D. G. Duarte, D. L. Ferreira-Alves, and M. Nakamura-Craig, "Possible participation of endogenous opioid peptides on the mechanism involved in analgesia induced by vouacapan," Life Sciences, vol. 50, no. 12, pp. 891-897, 1992.

[59] I. D. G. Duarte, D. L. Ferreira-Alves, D. P. Veloso, and M. Nakamura-Craig, "Evidence of the involvement of biogenic amines in the antinociceptive effect of a vouacapan extracted from Pterodon polygalaeflorusBenth," Journal of Ethnopharmacology, vol. 55, no. 1, pp. 13-18, 1996.

[60] H. M. Spindola, L. Servat, R. A. F. Rodrigues, I. M. O. Sousa, J. E. Carvalho, and M. A. Foglio, "Geranylgeraniol and $6 \alpha, 7 \beta$-dihydroxyvouacapan-17 $\beta$-oate methyl ester isolated from Pterodon pubescensBenth.: further investigation on the antinociceptive mechanisms of action," European Journal of Pharmacology, vol. 656, no. 1-3, pp. 45-51, 2011.

[61] K. C. C. Sabino, F. A. Castro, J. C. R. Oliveira, S. R. A. Dalmau, and M. G. P. Coelho, "Successful treatment of collagen-induced arthritis in mice with a hydroalcohol extract of seeds of Pterodon pubescens," Phytotherapy Research, vol. 13, no. 7, pp. 613-615, 1999.

[62] M. G. P. Coelho, K. C. C. Sabino, and S. R. Dalmau, "Immunomodulatory effects of sucupira (Pterodon pubescens) seed infusion on collagen-induced arthritis," Clinical and Experimental Rheumatology, vol. 22, no. 2, pp. 213-218, 2004.

[63] F. B. A. Paula, C. M. C. P. Gouvêa, P. P. Alfredo, and I. Salgado, "Protective action of a hexane crude extract of Pterodon emarginatus fruits against oxidative and nitrosative stress induced by acute exercise in rats," BMC Complementary and Alternative Medicine, vol. 5, article 17, 2005. 
[64] R. C. Dutra, M. N. Leite, and N. R. Barbosa, "Quantification of phenolic constituents and antioxidant activity of Pterodon emarginatus vogel seeds," International Journal of Molecular Sciences, vol. 9, no. 4, pp. 606-614, 2008.

[65] D. Santos Filho, S. J. Sarti, N. Katz et al., "Atividade quimioprofilática de sabonetes contendo óleo essencial de frutos de Pterodon pubescens na esquistossomose mansoni," Memórias do Instituto Oswaldo Cruz, vol. 82, pp. 343-345, 1987.

[66] N. Katz, D. Santos Filho, S. J. Sarti, N. M. Mendes, P. A. Rocha Filho, and N. Araujo, "Chemoprophylactic activity on Schistosomiasis mansoni of soaps containing essential oil from the fruits of Pterodon pubescens," Revista do Instituto de Medicina Tropical de Sao Paulo, vol. 35, no. 2, pp. 183-191, 1993.

[67] M. C. Omena, E. S. Bento, J. E. De Paula, and A. E. G. Sant'Ana, "Larvicidal diterpenes from Pterodon polygalaeflorus," VectorBorne and Zoonotic Diseases, vol. 6, no. 2, pp. 216-222, 2006.

[68] R. F. S. Menna-Barreto, G. A. T. Laranja, M. C. C. Silva et al., "Anti-trypanosoma cruzi activity of Pterodon pubescens seed oil: geranylgeraniol as the major bioactive component," Parasitology Research, vol. 103, no. 1, pp. 111-117, 2008.

[69] R. C. Dutra, F. G. Braga, E. S. Coimbra, A. D. Silva, and N. R. Barbosa, "Atividades antimicrobiana e leishmanicida das sementes de Pterodon emarginatus Vogel," Revista Brasileira de Farmacognosia, vol. 19, no. 2, pp. 429-435, 2009.

[70] M. R. F. Lima, E. C. P. A. Ximenes, J. S. Luna, and A. E. Sant'Ana, "The antibiotic activity of some Brazilian medicinal plants," Revista Brasileira de Farmacognosia, vol. 16, no. 3, pp. 300-306, 2006.

[71] C. E. M. De Toledo, E. A. Britta, L. F. Ceole et al., "Antimicrobial and cytotoxic activities of medicinal plants of the Brazilian cerrado, using Brazilian cachaça as extractor liquid," Journal of Ethnopharmacology, vol. 133, no. 2, pp. 420-425, 2011.

[72] R. D. M. Espíndola, R. P. Mazzantini, T. P. Ong, A. de Conti, R. Heidor, and F. S. Moreno, "Geranylgeraniol and $\beta$-ionone inhibit hepatic preneoplastic lesions, cell proliferation, total plasma cholesterol and DNA damage during the initial phases of hepatocarcinogenesis, but only the former inhibits NF- $\kappa \mathrm{B}$ activation," Carcinogenesis, vol. 26, no. 6, pp. 1091-1099, 2005.

[73] S. F. C. Mello, "Efeito da subfração 3 da fração hexânica do óleo de semente de Pterodon pubescens na proliferação de linhagem celularrr leucêmica humana," Revista Eletrônica-Novo Enfoque, vol. 5, pp. 1-15, 2007.

[74] S. P. Almeida, C. E. B. Proença, S. M. Sano, and J. F. Ribeiro, Cerrado: Espécies Vegetais Úteis, EMBRAPA-CPAC, Planaltina, Brazil, 1st edition, 1998.

[75] K. C. C. Sabino, C. R. M. Gayer, L. C. A. Vaz, L. R. L. Santos, I. Felzenszwalb, and M. G. P. Coelho, "In vitro and in vivo toxicological study of the Pterodon pubescens seed oil," Toxicology Letters, vol. 108, no. 1, pp. 27-35, 1999.

[76] F. J. F. Sant'Ana, J. N. Perin, U. O. Bilego, R. E. Rabelo, V. A. S. Vulcani, and E. M. N. Paula, "Intoxicação espontânea por Pterodon emarginatus (Fabaceae) em bovinos do Estado de Goiás," Pesquisa Veterinária Brasileira, vol. 32, pp. 485-489, 2012.

[77] J.C. T. Carvalho, Fitoterápicos antiinflamatórios: aspectos químicos, farmacológicos e aplicações terapêuticas, Tecmedd, Ribeirão Preto, Brazil, 2004.

[78] E. P. Feltrin and M. Chorilli, "Standardized dry extracts: current trend in phytotherapy," Revista Lusófona de Ciências e Tecnologias da Saúde, vol. 1, pp. 109-115, 2010.
[79] M. Heinrich, J. Barner, S. Gibbons, and E. M. Williamson, Fundamentals of Pharmacognosy and Phytotherapy, Elsevier, London, UK, 2nd edition, 2012. 


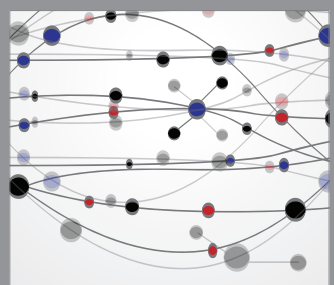

The Scientific World Journal
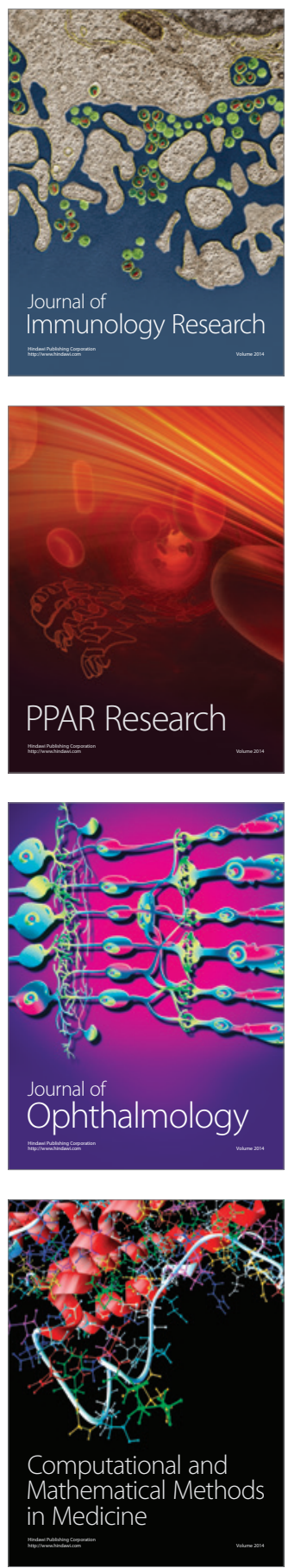

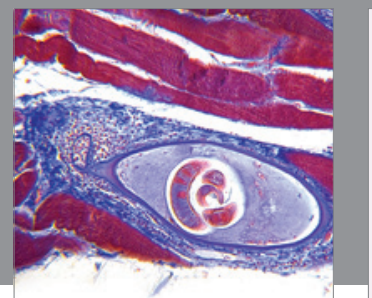

Gastroenterology

Research and Practice
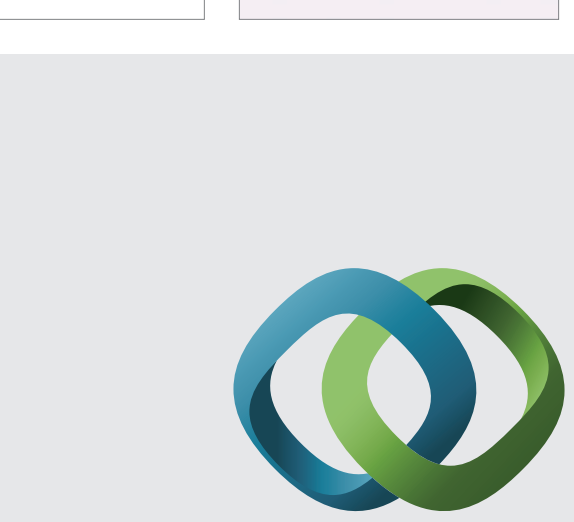

\section{Hindawi}

Submit your manuscripts at

http://www.hindawi.com
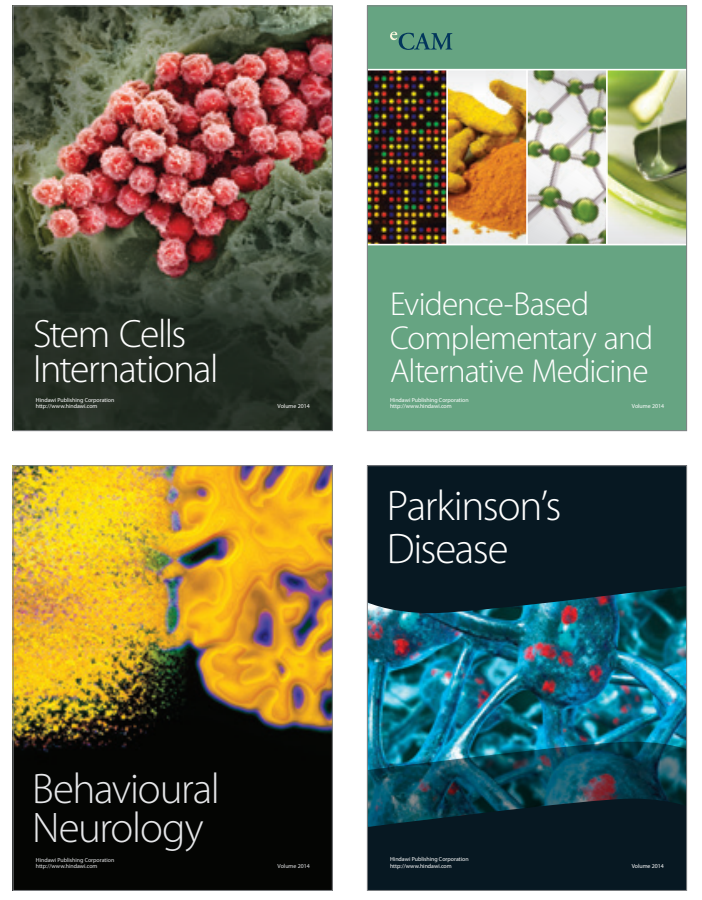
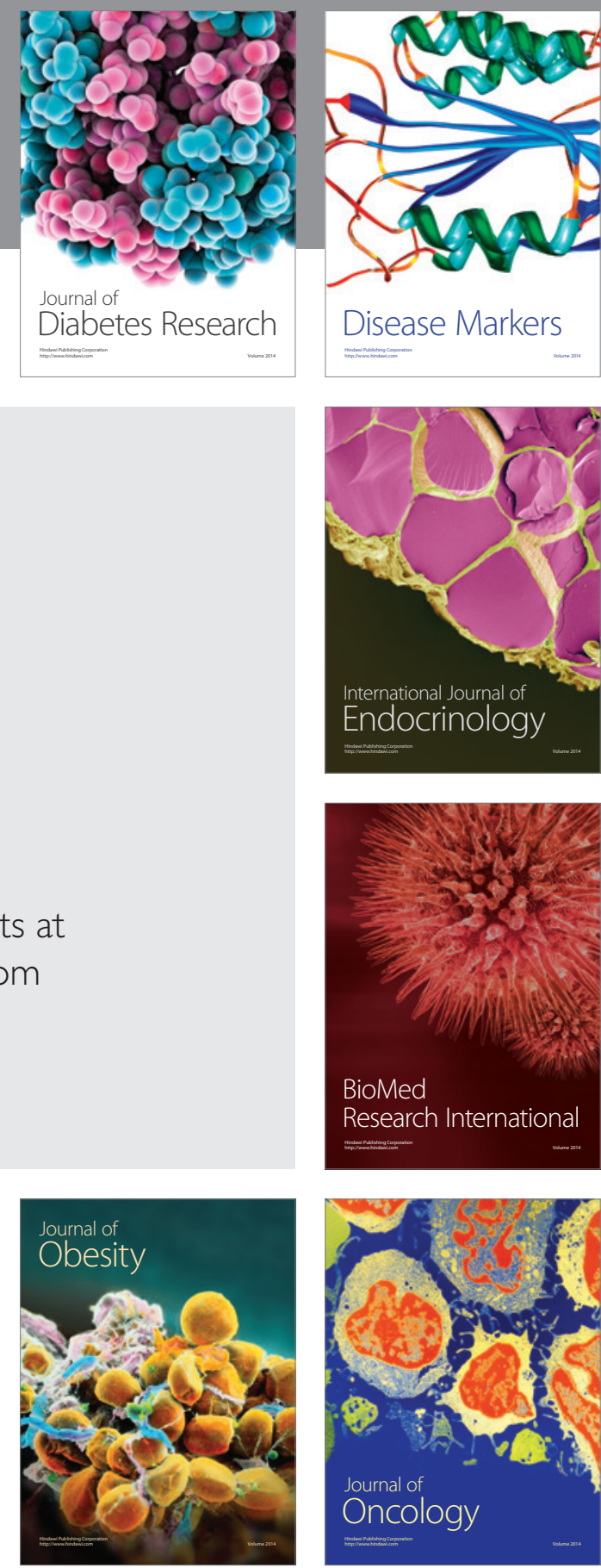

Disease Markers
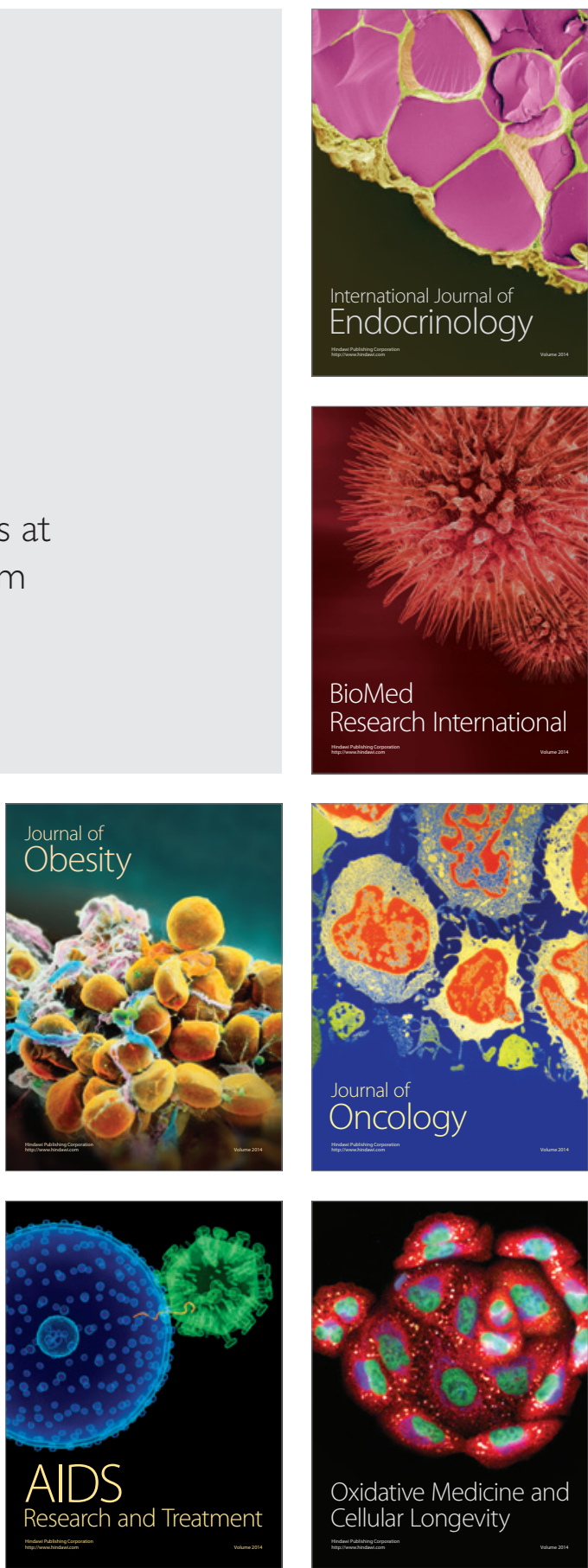